\title{
Biogeochemistry of the North Atlantic during Oceanic Anoxic Event 2: role of changes in ocean circulation and phosphorus input
}

\author{
I. Ruvalcaba Baroni ${ }^{1}$, R. P. M. Topper ${ }^{1}$, N. A. G. M. van Helmond ${ }^{1}$, H. Brinkhuis ${ }^{1,2}$, and C. P. Slomp ${ }^{1}$ \\ ${ }^{1}$ Utrecht University, Faculty of Geosciences, The Netherlands \\ ${ }^{2}$ Royal Netherlands Institute for Sea Research (NIOZ), Den Burg, Texel, The Netherlands
}

December 4, 2013

\section{Supplementary Information}

a)

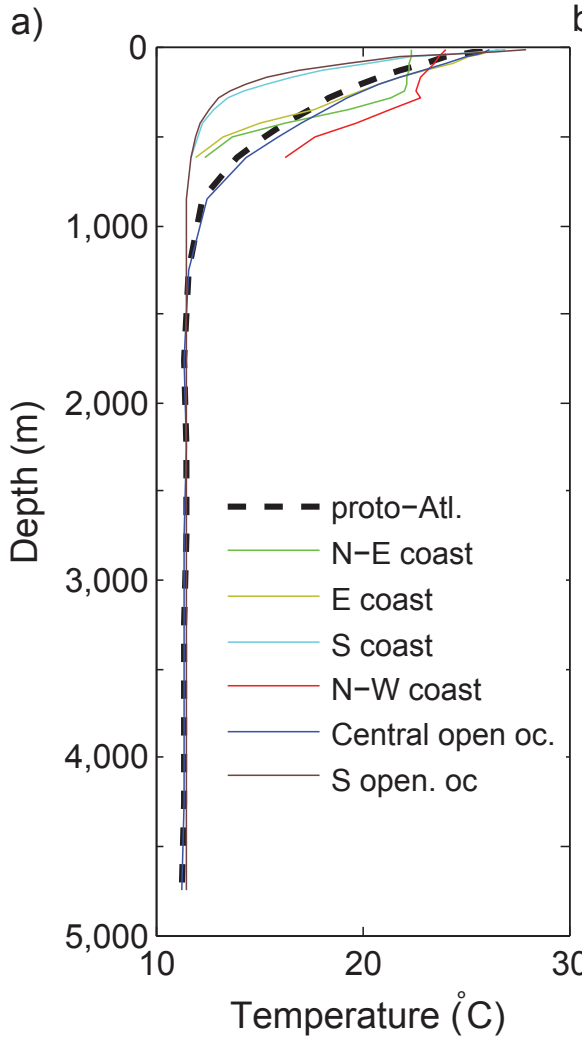

b)

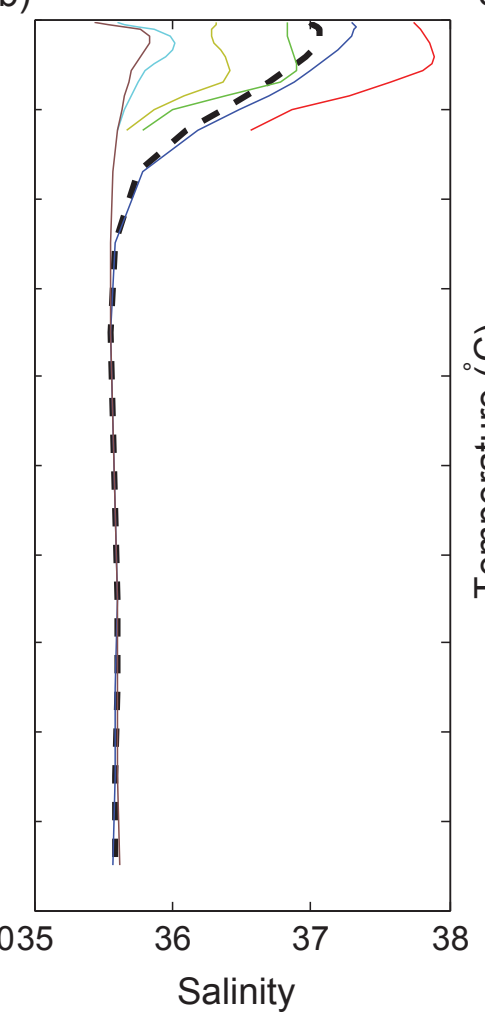

c)

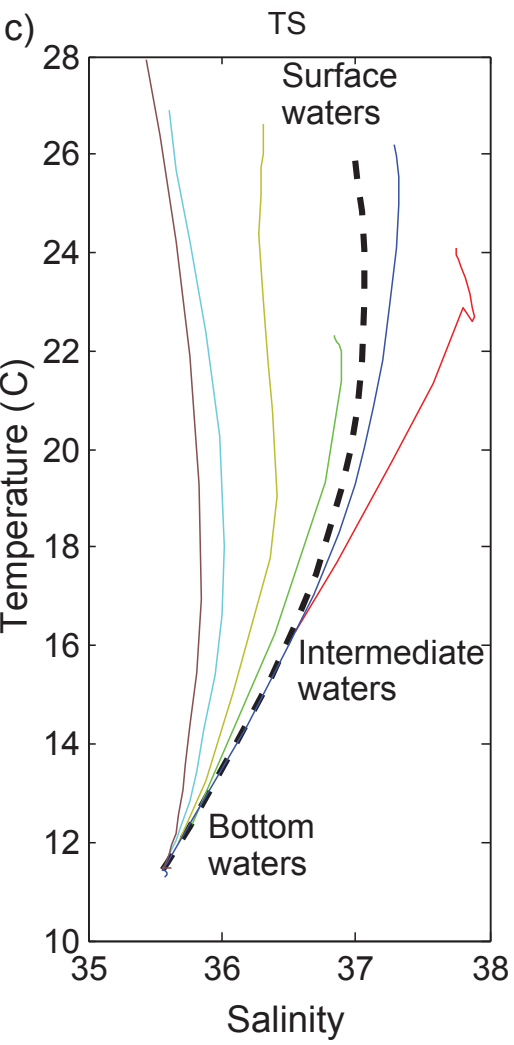

Figure S1: Profiles of a) mean temperature and b) salinity and c) a temperature (T)-salinity (S) diagram for several regions of the proto-North Atlantic, where the basin average is also shown with a dashed line (Topper et al., 2011). The TS diagram highlights that the proto-North Atlantic was poorly stratified. Note that the temperatures may be underestimated since the model uses yearly averaged air temperature as its forcing. 


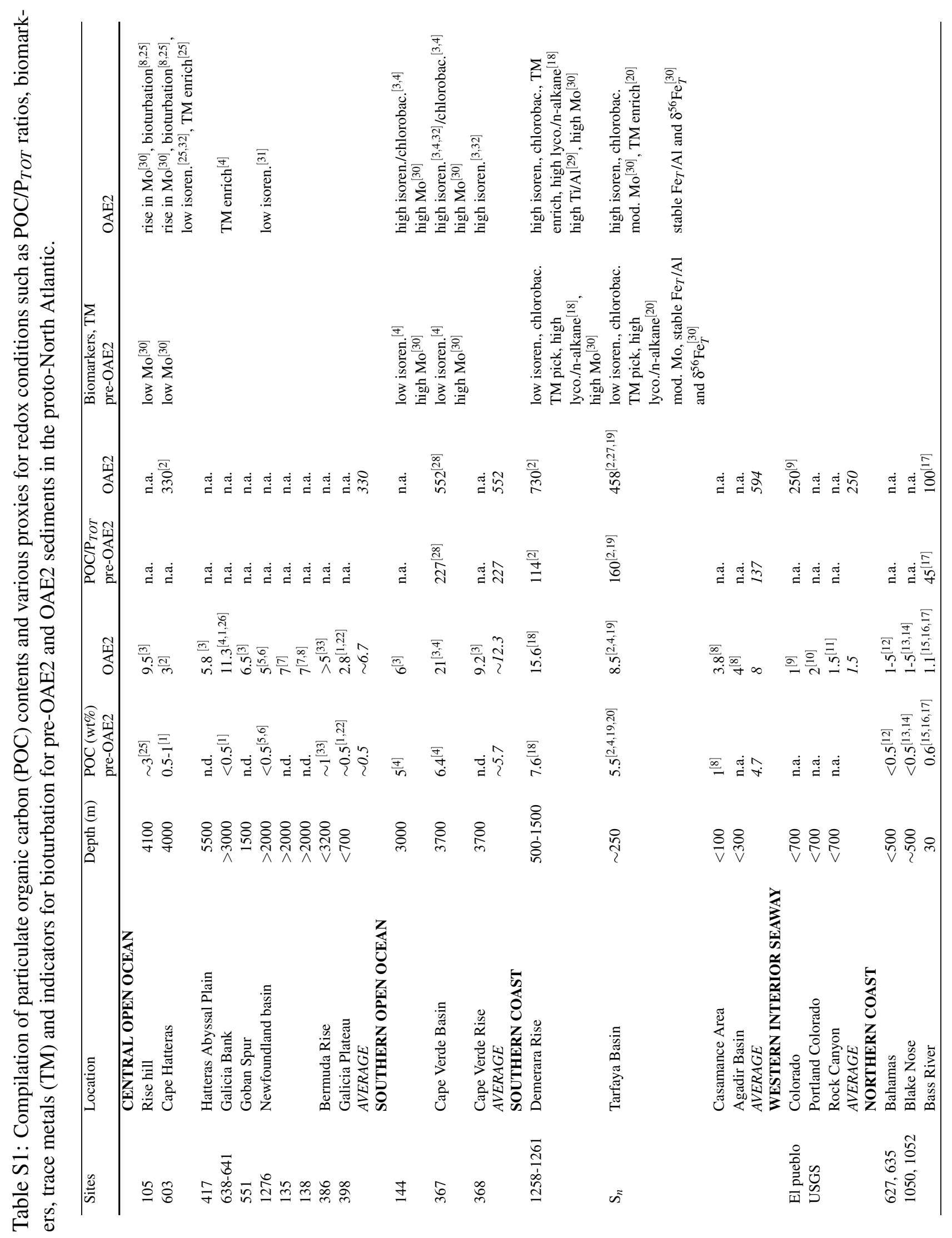




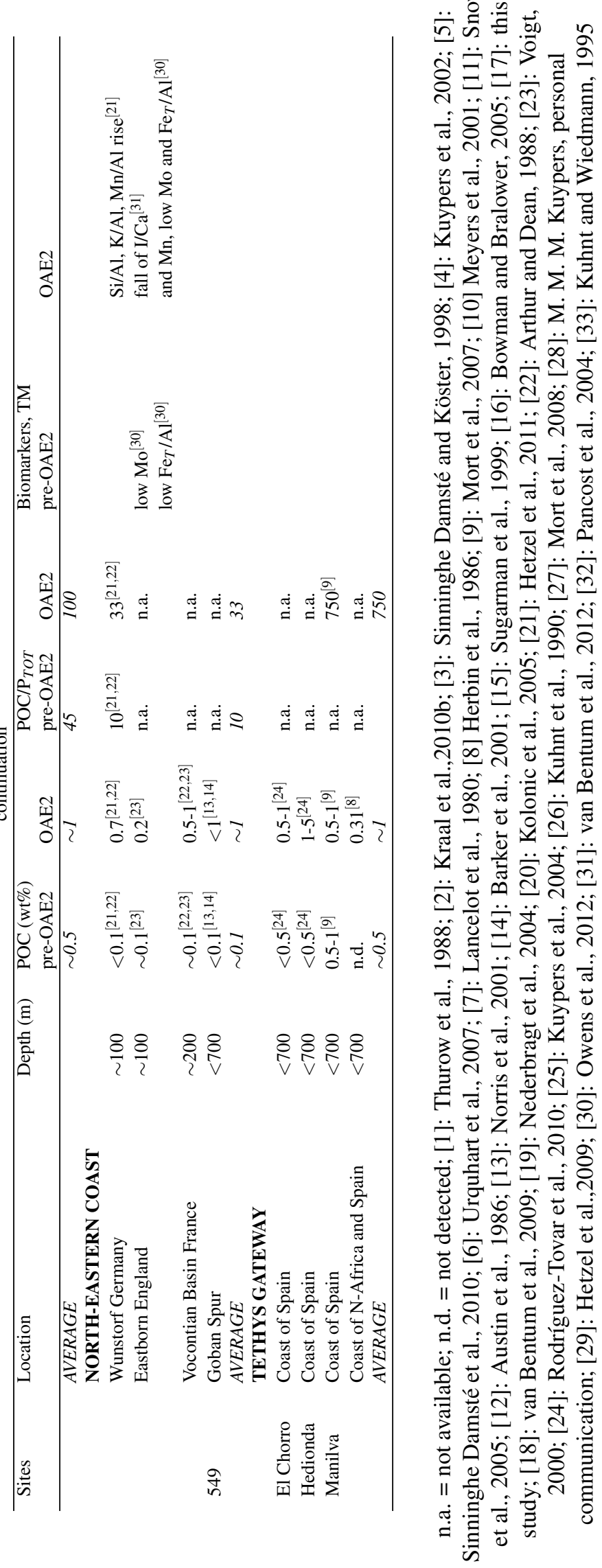


Table S2: Water cycle: Reservoirs and fluxes for pre-OAE2 and OAE2 conditions as implemented in the multibox model. Note that several fluxes change direction from pre-OAE2 to OAE2 conditions.

\begin{tabular}{|c|c|c|c|}
\hline $\begin{array}{l}\text { Box } \\
\text { Name }\end{array}$ & $\begin{array}{l}\text { Water reservoir } \\
\text { pre-OAE2 }\end{array}$ & OAE2 & $\begin{array}{l}\text { Description } \\
\text { units in } \mathrm{Tm}^{3}\end{array}$ \\
\hline W1s & 1522.11 & 1554.12 & Surface water of the central open ocean \\
\hline W1i & 8623.65 & 8805.83 & Intermediate water of the central open ocean \\
\hline W1b & 38518.87 & 40583.26 & Bottom water of the central open ocean \\
\hline W2s & 254.6 & 259.51 & Surface water of the southern open ocean \\
\hline $\mathrm{W} 2 \mathrm{i}$ & 1527.58 & 1557.09 & Intermediate water of the southern open ocean \\
\hline $\mathrm{W} 2 \mathrm{~b}$ & 7056.33 & 7408.83 & Bottom water of the southern open ocean \\
\hline W3s & 53.47 & 227.61 & Surface water of the Western Interior Seaway \\
\hline W3b & 139.12 & 387.49 & Shallow bottom water of the Western Interior Seaway \\
\hline $\mathrm{W} 4 \mathrm{~s}$ & 129.37 & 202.61 & Surface water of the northern coast \\
\hline W4b & 340.46 & 461.35 & Shallow bottom water of the northern coast \\
\hline W5s & 129.17 & 202.41 & Surface water of the southern coast \\
\hline W5b & 340.21 & 461.1 & Shallow bottom water of the southern coast \\
\hline W6s & 47.75 & 76.25 & Surface water of the north-eastern coast \\
\hline W6b & 128.28 & 180.06 & Shallow bottom water of the north-eastern coast \\
\hline W7s & 35.66 & 34.29 & Surface water of the Tethys gateway \\
\hline W7b & 91.35 & 125.63 & Shallow bottom water of the Tethys gateway \\
\hline Name & $\begin{array}{l}\text { Water flux (Sv) } \\
\text { pre-OAE2 }\end{array}$ & OAE2 & $\begin{array}{l}\text { Description } \\
\left(x 3.1536 \text { for } \operatorname{Tm}^{3} y-1\right)\end{array}$ \\
\hline F1 & 4.91 & 7.09 & Net surface water flux from W1s to the Pacific Ocean \\
\hline F3 & 9.26 & 15.15 & Net intermediate water flux from W1i to the Pacific Ocean \\
\hline F6 & 13.75 & 21.98 & Net bottom water flux from the Pacific Ocean to W1b \\
\hline F7 & 1.3 & 6.67 & Net surface water flux from the Tethys gateway to W7s \\
\hline F10 & 0.88 & 6.47 & Net bottom water flux from W7b to the Tethys gateway \\
\hline F11 & 1.32 & 1.32 & Evaporation in $\mathrm{W} 1 \mathrm{~s}$ \\
\hline F12 & 0.81 & 0.81 & Precipitation in $\mathrm{W} 1 \mathrm{~s}$ \\
\hline F13 & 6.57 & 7.46 & Surface water flux from W4s to W1s \\
\hline F14 & 0.59 & 3.36 & Surface water flux from W1s to W6s \\
\hline F15 & 0.65 & 4.15 & Surface water flux from W7s to W1s \\
\hline F16 & 10.6 & 17.13 & Downwelling from $\mathrm{W} 1 \mathrm{~s}$ to $\mathrm{W} 1 \mathrm{i}$ \\
\hline F17 & 2.89 & 7.83 & Upwelling from $\mathrm{W} 1 \mathrm{i}$ to $\mathrm{W} 1 \mathrm{~s}$ \\
\hline F18 & 1.02 & 1.17 & $\begin{array}{l}\text { Surface water flux from W5s to W2s } \\
\text { (Changes direction during OAE2) }\end{array}$ \\
\hline F19 & 1.75 & 2.49 & Surface water flux from W1s to W3s \\
\hline F20 & 10.35 & 9.25 & Intermediate water flux from $\mathrm{W} 1 \mathrm{i}$ to $\mathrm{W} 3 \mathrm{~b}$ \\
\hline $\mathrm{F} 21$ & 5.64 & 13.77 & Shallow bottom water flux from W4b to W1i \\
\hline $\mathrm{F} 22$ & 0.61 & 2.89 & Intermediate water flux from W1i to W6b \\
\hline $\mathrm{F} 23$ & 0.12 & 8.64 & Intermediate water flux from $\mathrm{W} 1 \mathrm{i}$ to $\mathrm{W} 7 \mathrm{~b}$ \\
\hline F24 & 4.65 & 2.73 & Shallow bottom water flux from W5b to W2i \\
\hline F25 & 0.12 & 5.86 & Deep bottom water flux from $\mathrm{W} 1 \mathrm{~b}$ to $\mathrm{W} 7 \mathrm{~b}$ \\
\hline F26 & 1.71 & 1.75 & Downwelling water flux from W7s to W7b \\
\hline $\mathrm{F} 27$ & 2.12 & 3.44 & Upwelling water flux from bottom W7b to W7s \\
\hline F28 & 0.75 & 1.31 & Downwelling water flux form $\mathrm{W} 5 \mathrm{~s}$ to $\mathrm{W} 5 \mathrm{~b}$ \\
\hline F29 & 4.38 & 5.74 & Upwelling water flux from W5b to W5s \\
\hline
\end{tabular}


continuation

\begin{tabular}{|c|c|c|c|}
\hline Name & $\begin{array}{l}\text { Water flux (Sv) } \\
\text { pre-OAE2 }\end{array}$ & OAE2 & $\begin{array}{l}\text { Description } \\
\left(x 3.1536 \text { for } \operatorname{Tm}^{3} y-1\right)\end{array}$ \\
\hline F30 & 0.3 & 0.3 & River water flux to W5st \\
\hline F31 & 5.21 & 6.05 & Downwelling water flux from W3s to W3b \\
\hline F32 & 6.9 & 7.38 & Upwelling water flux from $\mathrm{W} 3 \mathrm{~b}$ to $\mathrm{W} 3 \mathrm{~s}$ \\
\hline F33 & 5.39 & 3.83 & Downwelling water flux from $\mathrm{W} 4 \mathrm{~s}$ to $\mathrm{W} 4 \mathrm{~b}$ \\
\hline F34 & 8.24 & 4.62 & Upwelling water flux from $\mathrm{W} 4 \mathrm{~b}$ to $\mathrm{W} 4 \mathrm{~s}$ \\
\hline F35 & 1.1 & 3.17 & Downwelling water flux from W6s to W6b \\
\hline F36 & 0.43 & 1.15 & Upwelling water flux from W6b to W6s \\
\hline F37 & 8.38 & 19.16 & Downwelling water flux from W1i to W1b \\
\hline F38 & 21.23 & 33.31 & Upwelling water flux from $\mathrm{W} 1 \mathrm{~b}$ to $\mathrm{W} 1 \mathrm{i}$ \\
\hline F39 & 3.53 & 3.97 & Surface water flux from W3s to W4s \\
\hline F40 & 0.08 & 2.61 & Surface water flux from W6s to W4s \\
\hline $\mathrm{F} 41$ & 0.15 & 1.25 & Surface water flux from W7s to W6s \\
\hline $\mathrm{F} 42$ & 0.91 & 2.95 & Surface water flux from W7s to W5s \\
\hline F43 & 0.41 & 4.62 & Shallow bottom water flux from $\mathrm{W} 7 \mathrm{~b}$ to $\mathrm{W} 5 \mathrm{~b}$ \\
\hline $\mathrm{F} 44$ & 1.46 & 1.73 & $\begin{array}{l}\text { Shallow bottom water flux from W6b to W7b } \\
\text { (Changes direction during OAE2) }\end{array}$ \\
\hline F45 & 0.18 & 6.63 & $\begin{array}{l}\text { Shallow bottom water flux from W4b to W6b } \\
\text { (Changes direction during OAE2) }\end{array}$ \\
\hline F46 & 8.67 & 7.93 & Shallow bottom water flux from W3b to W4b \\
\hline F47 & 3.85 & 4.59 & Surface water flux from W1s to W2s \\
\hline F48 & 8.27 & 6.87 & Surface water flux from W2s to W1s \\
\hline F49 & 8.34 & 2.1 & Intermediate water flux from $\mathrm{W} 1 \mathrm{i}$ to $\mathrm{W} 5 \mathrm{~b}$ \\
\hline F50 & 9.92 & 11 & Intermediate water flux from $\mathrm{W} 1 \mathrm{i}$ to $\mathrm{W} 2 \mathrm{i}$ \\
\hline F51 & 12.42 & 11.79 & Intermediate water flux from $\mathrm{W} 2 \mathrm{i}$ to $\mathrm{W} 1 \mathrm{i}$ \\
\hline F52 & 15.37 & 17.73 & Deep bottom water flux from $\mathrm{W} 1 \mathrm{~b}$ to $\mathrm{W} 2 \mathrm{~b}$ \\
\hline F53 & 14.6 & 15.76 & Deep bottom water flux from $\mathrm{W} 2 \mathrm{~b}$ to $\mathrm{W} 1 \mathrm{~b}$ \\
\hline F54 & 3.82 & 8.85 & Surface water flux from W5s to W1s \\
\hline F55 & 0.12 & 0.15 & Downwelling water flux from W2s to W2i \\
\hline F56 & 3.51 & 3.6 & Upwelling water flux from W2i to W2s \\
\hline F57 & 0.37 & 0.37 & Downwelling water flux from W2i to W2b \\
\hline F58 & 1.62 & 1.9 & Upwelling water flux from bottom W2b to W2i \\
\hline F59 & 0.48 & 0.45 & $\begin{array}{l}\text { Shallow bottom water flux from W5b to W2b } \\
\text { (Changes direction during OAE2) }\end{array}$ \\
\hline R3 & 0.1 & 0.15 & River water flux to $\mathrm{W} 3 \mathrm{~s}$ \\
\hline $\mathrm{R} 4$ & 0.1 & 0.1 & River water flux to W4s \\
\hline R6 & 0.01 & 0.01 & River water flux to W6s \\
\hline
\end{tabular}


Table S3: Carbon cycle: Reservoir sizes and fluxes for pre-OAE2 and OAE2 conditions and pre-OAE2 biogeochemical fluxes as implemented in the multi-box model. Note that all OAE2 reservoirs and fluxes, including the ones in Table S4 and S5, are the ones obtained after equilibrium.

\begin{tabular}{|c|c|c|c|}
\hline Name & $\begin{array}{l}\text { C reservoir } \\
\text { pre-OAE2 }\end{array}$ & OAE2 & $\begin{array}{l}\text { Description } \\
\text { units in Tmol C }\end{array}$ \\
\hline POC1s & 4.84 & 4.54 & Organic $\mathrm{C}$ in the surface water of the central open ocean \\
\hline POC1i & 9.14 & 8.58 & Organic $\mathrm{C}$ in the intermediate water of the central open ocean \\
\hline POC1b & 8.17 & 7.67 & Organic $\mathrm{C}$ in the bottom water of the central open ocean \\
\hline $\mathrm{POC} 2 \mathrm{~s}$ & 2.16 & 1.74 & Organic $\mathrm{C}$ in the surface water of the southern open ocean \\
\hline $\mathrm{POC} 2 \mathrm{i}$ & 6.48 & 5.23 & Organic $\mathrm{C}$ in the intermediate water of the southern open ocean \\
\hline $\mathrm{POC} 2 \mathrm{~b}$ & 2.24 & 1.81 & Organic $\mathrm{C}$ in the bottom water of the southern open ocean \\
\hline $\mathrm{POC} 3 \mathrm{~s}$ & 0.23 & 0.52 & Organic $\mathrm{C}$ in the surface water of the Western Interior Seaway \\
\hline $\mathrm{POC} 3 \mathrm{~b}$ & 0.01 & 0.03 & Organic $\mathrm{C}$ in the bottom water of the Western Interior Seaway \\
\hline $\mathrm{POC} 4 \mathrm{~s}$ & 0.69 & 0.49 & Organic $\mathrm{C}$ in the surface water of the northern coast \\
\hline $\mathrm{POC} 4 \mathrm{~b}$ & 0.07 & 0.05 & Organic $\mathrm{C}$ in the bottom water of the northern coast \\
\hline POC5s & 1.1 & 1.37 & Organic $\mathrm{C}$ in the surface water of the southern coast \\
\hline POC5b & 0.29 & 0.36 & Organic $\mathrm{C}$ in the bottom water of the southern coast \\
\hline POC6s & 0.05 & 0.07 & Organic $\mathrm{C}$ in the surface water of the north-eastern coast \\
\hline POC6b & 0.01 & 0.02 & Organic $\mathrm{C}$ in the bottom water of the north-eastern coast \\
\hline POC7s & 0.04 & 0.03 & Organic $\mathrm{C}$ in the surface water of the Tethys gatway \\
\hline POC7b & 0.01 & 0.01 & Organic $\mathrm{C}$ in the bottom water of the Tethys gatway \\
\hline Name & $\begin{array}{l}\mathrm{C} \text { flux } \\
\text { pre-OAE2 }\end{array}$ & OAE2 & $\begin{array}{l}\text { Description } \\
\text { units in Tmol } \mathrm{C} y-1\end{array}$ \\
\hline BCF1 & 163.79 & 153.79 & Primary productivity in the central open ocean \\
\hline $\mathrm{BCF} 2$ & 142.73 & 134.01 & Remineralization in the surface water of the central open ocean \\
\hline $\mathrm{BCF} 3$ & 16.38 & 15.28 & Remineralization in the intermediate water of the central open ocean \\
\hline $\mathrm{BCF} 4$ & 4.67 & 4.38 & Remineralization in the bottom water of the central open ocean \\
\hline BCF5 & 0.02 & 0.015 & Organic $\mathrm{C}$ burial in the central open ocean \\
\hline BCF6 & 224 & 180.89 & Primary productivity in the southern open ocean \\
\hline BCF7 & 195.2 & 157.62 & Remineralization in the surface water of the southern open ocean \\
\hline $\mathrm{BCF} 8$ & 22.4 & 18.09 & Remineralization in the intermediate water of the southern open ocean \\
\hline BCF9 & 6.38 & 5.15 & Remineralization in the bottom water of the southern open ocean \\
\hline BCF10 & 0.03 & 0.02 & Organic $\mathrm{C}$ burial in the southern open ocean \\
\hline BCF11 & 45.76 & 105.16 & Primary productivity in the Western Interior Seaway \\
\hline BCF12 & 39.81 & 91.49 & Remineralization in the surface water of the Western Interior Seaway \\
\hline BCF13 & 5.83 & 13.39 & Remineralization in the shallow bottom water of the Western Interior Seaway \\
\hline BCF14 & $0.16^{*}$ & 0.28 & Organic $\mathrm{C}$ burial in the Western Interior Seaway \\
\hline BCF15 & 104.64 & 75.16 & Primary productivity in the northern coast \\
\hline BCF16 & 91.04 & 65.39 & Remineralization in the surface water of the northern coast \\
\hline BCF17 & 13.31 & 9.57 & Remineralization in the shallow bottom water of the northern coast \\
\hline BCF18 & $0.29 *$ & 0.2 & Organic $\mathrm{C}$ burial in the northern coast \\
\hline BCF19 & 168.3 & 210.01 & Primary productivity in the southern coast \\
\hline BCF20 & 146.42 & 182.7 & Remineralization in the surface water of the southern coast \\
\hline BCF21 & 21.25 & 26.52 & Remineralization in the shallow bottom water of the southern coast \\
\hline BCF22 & $0.63^{*}$ & 0.77 & Organic $\mathrm{C}$ burial in the southern coast \\
\hline BCF23 & 4.25 & 6.14 & Primary productivity in the north-eastern coast \\
\hline BCF24 & 3.7 & 5.34 & Remineralization in the surface water of the north-eastern coast \\
\hline
\end{tabular}


continuation

\begin{tabular}{|c|c|c|c|}
\hline Name & $\begin{array}{l}\text { C flux } \\
\text { pre-OAE2 }\end{array}$ & OAE2 & $\begin{array}{l}\text { Description } \\
\text { units in Tmol } \mathrm{C} y-1\end{array}$ \\
\hline BCF25 & 0.54 & 0.78 & Remineralization in the shallow bottom water of the north-eastern coast \\
\hline BCF26 & 0.01 & 0.02 & Organic $\mathrm{C}$ burial in the north-eastern coast \\
\hline BCF27 & 24 & 22.19 & Primary productivity in the Tethys gateway \\
\hline BCF28 & 20.88 & 19.3 & Remineralization in the surface water of the Tethys gateway \\
\hline BCF29 & 3.06 & 2.83 & Remineralization in the shallow bottom water of the Tethys gateway \\
\hline BCF30 & 0.069 & 0.057 & Organic $\mathrm{C}$ burial in the Tethys gateway \\
\hline BCF31 & 21.06 & 19.78 & Organic $\mathrm{C}$ export to the intermediate water in the central open ocean \\
\hline BCF32 & 4.68 & 4.4 & Organic $\mathrm{C}$ export to the bottom water in the central open ocean \\
\hline BCF33 & 28.8 & 23.26 & Organic $\mathrm{C}$ export to the intermediate water in the southern open ocean \\
\hline BCF34 & 6.4 & 5.17 & Organic $\mathrm{C}$ export to the bottom water in the southern open ocean \\
\hline PCF35 & 5.95 & 13.67 & Organic $\mathrm{C}$ export to the shallow bottom water in the Western Interior Seaway \\
\hline BCF36 & 13.60 & 9.77 & Organic $\mathrm{C}$ export to the shallow bottom water in the northern coast \\
\hline BCF37 & 21.88 & 27.3 & Organic $\mathrm{C}$ export to the shallow bottom water in the southern coast \\
\hline BCF38 & 0.55 & 0.8 & Organic $\mathrm{C}$ export to the shallow bottom water in the north-eastern coast \\
\hline BCF39 & 3.12 & 2.89 & Organic $\mathrm{C}$ export to the shallow bottom water in the Tethys gateway \\
\hline
\end{tabular}


Table S4: Phosphorus cycle: Reservoir sizes and fluxes for pre-OAE2 and OAE2 conditions.

\begin{tabular}{|c|c|c|c|}
\hline Name & $\begin{array}{l}\text { P reservoir } \\
\text { pre-OAE2 }\end{array}$ & OAE2 & $\begin{array}{l}\text { Description } \\
\text { units in Tmol P }\end{array}$ \\
\hline SRP1s & 0.68 & 0.64 & Soluble reactive $\mathrm{P}$ in the surface water of the open ocean \\
\hline SRP1i & 13.6 & 10.48 & Soluble reactive $\mathrm{P}$ in the intermediate water of the open ocean \\
\hline SRP1b & 59.7 & 52.86 & Soluble reactive $\mathrm{P}$ in the bottom water of the open ocean \\
\hline SRP2s & 0.04 & 0.03 & Soluble reactive $\mathrm{P}$ in the surface water of the southern open ocean \\
\hline SRP2i & 3.29 & 2.64 & Soluble reactive $\mathrm{P}$ in the intermediate water of the southern open ocean \\
\hline $\mathrm{SRP} 2 b$ & 11.98 & 10.34 & Soluble reactive $\mathrm{P}$ in the bottom water of the southern open ocean \\
\hline SRP3s & 0.06 & 0.13 & Soluble reactive $\mathrm{P}$ in the surface water of the Western Interior Seaway \\
\hline SRP3b & 0.21 & 0.47 & Soluble reactive $\mathrm{P}$ in the bottom water of the Western Interior Seaway \\
\hline SRP4s & 0.15 & 0.1 & Soluble reactive $\mathrm{P}$ in the surface water of the northern coast \\
\hline SRP4b & 0.56 & 0.52 & Soluble reactive $\mathrm{P}$ in the shallow bottom water of the northern coast \\
\hline SRP5s & 0.08 & 0.1 & Soluble reactive $\mathrm{P}$ in the surface water of the southern coast \\
\hline SRP5b & 0.73 & 0.95 & Soluble reactive $\mathrm{P}$ in the shallow bottom water of the southern coast \\
\hline SRP6s & 0.02 & 0.04 & Soluble reactive $\mathrm{P}$ in the surface water of the north-eastern coast \\
\hline SRP6b & 0.13 & 0.17 & Soluble reactive $\mathrm{P}$ in the shallow bottom water of the north-eastern coast \\
\hline SRP7s & 0.01 & 0.01 & Soluble reactive $\mathrm{P}$ in the surface water of the Tethys gateway \\
\hline SRP7b & 0.09 & 0.15 & Soluble reactive $\mathrm{P}$ in the shallow bottom water of the Tethys gateway \\
\hline POP1s & 0.046 & 0.04 & Organic $P$ in the surface water of the open ocean \\
\hline POP1i & 0.086 & 0.08 & Organic $\mathrm{P}$ in the intermediate water of the open ocean \\
\hline POP1b & 0.077 & 0.07 & Organic $\mathrm{P}$ in the bottom water of the open ocean \\
\hline $\mathrm{POP} 2 \mathrm{~s}$ & 0.02 & 0.02 & Organic $P$ in the surface water of the southern open ocean \\
\hline POP2i & 0.06 & 0.05 & Organic $\mathrm{P}$ in the intermediate water of the southern open ocean \\
\hline POP2b & 0.02 & 0.02 & Organic $\mathrm{P}$ in the bottom water of the southern open ocean \\
\hline $\mathrm{POP} 3 \mathrm{~s}$ & 0.002 & 0.005 & Organic $\mathrm{P}$ in the surface water of the Western Interior Seaway \\
\hline POP3b & 0.0001 & 0.0003 & Organic $\mathrm{P}$ in the shallow bottom water of the Western Interior Seaway \\
\hline $\mathrm{POP} 4 \mathrm{~s}$ & 0.006 & 0.005 & Organic $\mathrm{P}$ in the surface water of the northern coast \\
\hline POP4b & 0.0007 & 0.0005 & Organic $\mathrm{P}$ in the shallow bottom water of the northern coast \\
\hline POP5s & 0.01 & 0.01 & Organic $\mathrm{P}$ in the surface water of the southern coast \\
\hline POP5b & 0.003 & 0.003 & Organic $\mathrm{P}$ in the shallow bottom water of the southern coast \\
\hline POP6s & 0.0005 & 0.0007 & Organic $P$ in the surface water of the north-eastern coast \\
\hline POP6b & 0.0001 & 0.0002 & Organic $\mathrm{P}$ in the shallow bottom water of the north-eastern coast \\
\hline POP7s & 0.0004 & 0.0003 & Organic $P$ in the surface water of the Tethys gateway \\
\hline POP7b & 0.0001 & 0.0001 & Organic $\mathrm{P}$ in the shallow bottom water of the Tethys gateway \\
\hline \multirow[t]{2}{*}{ Name } & $\begin{array}{l}\text { P flux } \\
\text { pre-OAE2 }\end{array}$ & OAE2 & $\begin{array}{l}\text { Description } \\
\text { units in Tmol } \mathrm{P} y-1\end{array}$ \\
\hline & & & Fluxes coupled to the water cycle \\
\hline PF1 & 0.07 & 0.09 & Surface $[\mathrm{SRP}]$ of the central open ocean times F1 \\
\hline PF3 & 0.46 & 0.57 & Intermediate $[\mathrm{SRP}]$ of the central open ocean times F3 \\
\hline PF6 & 0.55 & 0.88 & Bottom [SRP] of the Pacific Ocean times F6 \\
\hline PF7 & 0.004 & 0.02 & Surface $[\mathrm{SRP}]$ of the Tethys gateway times F7 \\
\hline PF10 & 0.03 & 0.24 & Bottom [SRP] of the Tethys gateway times F10 \\
\hline PF13 & 0.23 & 0.12 & Surface $[\mathrm{SRP}]$ of the Tethys gateway times F13 \\
\hline PF14 & 0.008 & 0.04 & Surface $[\mathrm{SRP}]$ of central open ocean times F14 \\
\hline PF15 & 0.008 & 0.05 & Surface $[\mathrm{SRP}]$ of the Tethys gateway times F15 \\
\hline PF16 & 0.15 & 0.22 & Surface [SRP] of the central open ocean times F16 (downwelling) \\
\hline
\end{tabular}


continuation

\begin{tabular}{|c|c|c|c|}
\hline Name & $\begin{array}{l}\text { P flux } \\
\text { pre-OAE2 }\end{array}$ & OAE2 & $\begin{array}{l}\text { Description } \\
\text { units in Tmol } \mathrm{P} y-1\end{array}$ \\
\hline PF17 & 0.14 & 0.29 & Intermediate [SRP] of the central open ocean times F17 (upwelling) \\
\hline PF18 & 0.02 & 0.005 & $\begin{array}{l}\text { Surface }[\mathrm{SRP}] \text { of the southern coast times F18 in pre-OAE2 } \\
\text { Surface }[\mathrm{SRP}] \text { of the southern open ocean times F18 in OAE2 }\end{array}$ \\
\hline PF19 & 0.02 & 0.03 & Surface $[\mathrm{SRP}]$ of the central open ocean times F19 \\
\hline PF20 & 0.51 & 0.35 & Intermediate $[\mathrm{SRP}]$ of the central open ocean times F20 \\
\hline PF21 & 0.29 & 0.48 & Bottom [SRP] of the northern coast times F21 \\
\hline PF22 & 0.03 & 0.11 & Intermediate $[\mathrm{SRP}]$ of the central open ocean times F22 \\
\hline PF23 & 0.006 & 0.32 & Intermediate $[\mathrm{SRP}]$ of th central open ocean times F23 \\
\hline PF24 & 0.32 & 0.18 & Bottom [SRP] of the southern coast times F24 \\
\hline PF25 & 0.006 & 0.24 & Bottom [SRP] of the central open ocean times F25 \\
\hline PF26 & 0.02 & 0.02 & Surface $[\mathrm{SRP}]$ of the Tethys gateway times F26 (downwelling) \\
\hline PF27 & 0.07 & 0.13 & Bottom [SRP] of the Tethys gateway times F27 (upwelling) \\
\hline PF28 & 0.02 & 0.02 & Surface [SRP] of the southern coast times F28 (downwelling) \\
\hline PF29 & 0.3 & 0.37 & Bottom [SRP] of the southern coast times F29 (upwelling) \\
\hline PF30 & 0.01 & 0.01 & [SRP] of the South river times F30 \\
\hline PF31 & 0.18 & 0.11 & Surface [SRP] of the Western Interior Seaway times F31 (downwelling) \\
\hline PF32 & 0.33 & 0.28 & Bottom [SRP] of the Western Interior Seaway times F32 (upwelling) \\
\hline PF33 & 0.19 & 0.06 & Surface [SRP] of the northern coast times F33 (downwelling) \\
\hline PF34 & 0.43 & 0.16 & Bottom [SRP] of the northern coast itmes F34 (upwelling) \\
\hline PF35 & 0.02 & 0.05 & Surface [SRP] of the north-eastern coast times F35 (downwelling) \\
\hline PF36 & 0.01 & 0.03 & Bottom [SRP] of the north-eastern coast times F36 (upwelling) \\
\hline PF37 & 0.42 & 0.72 & Intermediate $[\mathrm{SRP}]$ of the central open ocean times F37 \\
\hline PF38 & 1.04 & 1.37 & Bottom [SRP] of the cental open ocean times F38 \\
\hline PF39 & 0.12 & 0.07 & Surface [SRP] of the Western Interior Seaway times F39 \\
\hline PF40 & 0.001 & 0.04 & Surface [SRP] of the north-eastern coast times F40 \\
\hline PF41 & 0.002 & 0.02 & Surface $[\mathrm{SRP}]$ ot the Tethys gateway times F41 \\
\hline PF42 & 0.01 & 0.04 & Surface $[\mathrm{SRP}]$ of the Tethys gateway times F42 \\
\hline PF43 & 0.01 & 0.17 & Bottom [SRP] of the Tethys gateway times F43 \\
\hline PF44 & 0.05 & 0.07 & $\begin{array}{l}\text { Bottom [SRP] of the north-eastern coast times F44 in pre-OAE2 } \\
\text { Bottom [SRP] of the Tethys gateway times F44 in OAE2 }\end{array}$ \\
\hline PF45 & 0.01 & 0.19 & $\begin{array}{l}\text { Bottom [SRP] of the northern coast times F } 45 \\
\text { Bottom [SRP] of the north-eastern coast times F45 }\end{array}$ \\
\hline PF46 & 0.42 & 0.3 & Bottom [SRP] of the northern coast times F46 \\
\hline PF47 & 0.05 & 0.06 & Surface $[\mathrm{SRP}]$ of the central open ocean times F47 \\
\hline PF48 & 0.04 & 0.03 & Surface $[\mathrm{SRP}]$ of the southern open ocean times F48 \\
\hline PF49 & 0.41 & 0.08 & Intermediate $[\mathrm{SRP}]$ of the central open ocean times F49 \\
\hline PF50 & 0.49 & 0.41 & Intermediate $[\mathrm{SRP}]$ of the central open ocean times F50 \\
\hline PF51 & 0.84 & 0.63 & Intermediate $[\mathrm{SRP}]$ of the southern open ocean times F51 \\
\hline PF52 & 0.75 & 0.73 & Bottom [SRP] of the central open ocean times F52 \\
\hline PF53 & 0.78 & 0.69 & Bottom [SRP] of the southern open ocean times F53 \\
\hline PF54 & 0.08 & 0.14 & Surface $[\mathrm{SRP}]$ of the southern coast times F54 \\
\hline PF55 & 0.0006 & 0.0006 & Surface $[\mathrm{SRP}]$ of the southern open ocean times F55 (downwelling) \\
\hline PF56 & 0.24 & 0.19 & Intermediate [SRP] of the southern open ocean times F56 (upwelling) \\
\hline PF57 & 0.03 & 0.02 & Intermediate [SRP] of the southern open ocean times F57 \\
\hline PF58 & 0.09 & 0.08 & Bottom [SRP] of the southern open ocean times F58 \\
\hline PF59 & 0.03 & 0.02 & Bottom [SRP] of the southern coast times F59 in pre-OAE2 \\
\hline
\end{tabular}


continuation

\begin{tabular}{|c|c|c|c|}
\hline Name & $\begin{array}{l}\text { P flux } \\
\text { pre-OAE2 }\end{array}$ & OAE2 & $\begin{array}{l}\text { Description } \\
\text { units in Tmol } \mathrm{P} y-1\end{array}$ \\
\hline PR3 & 0.0004 & 0.0006 & $\begin{array}{l}\text { Bottom [SRP] of the southern open ocean times F59 in OAE2 } \\
\text { [SRP] of the North-West river times R3 }\end{array}$ \\
\hline PR4 & 0.0018 & 0.0018 & [SRP] of the North river times R4 \\
\hline PR6 & 0.00001 & 0.00001 & $\begin{array}{l}{[\mathrm{SRP}] \text { of the north-eastern river times R6 }} \\
\text { Fluxes coupled to the } \mathbf{C} \text { and } \mathbf{O}_{2} \text { cycles }\end{array}$ \\
\hline BPF1 & 1.55 & 1.45 & SRP uptake in the central open ocean \\
\hline BPF2 & 1.35 & 1.26 & SRP release in the surface water of the central open ocean \\
\hline BPF3 & 0.155 & 0.15 & SRP release in the intermediate water of the central open ocean \\
\hline BPF4 & 0.04 & 0.04 & SRP release in the bottom water of the central open ocean \\
\hline BPF5 & 0.0001 & 0.0001 & Organic P burial in the central open ocean \\
\hline BPF6 & 2.11 & 1.71 & SRP uptake in the southern open ocean \\
\hline BPF7 & 1.84 & 1.49 & SRP release in the surface water of the southern open ocean \\
\hline BPF8 & 0.21 & 0.17 & SRP release in the intermediate water of the southern open ocean \\
\hline BPF9 & 0.06 & 0.05 & SRP release in the bottom water of the southern open ocean \\
\hline BPF10 & 0.0002 & 0.0002 & Organic $\mathrm{P}$ burial in the southern open ocean \\
\hline BPF11 & 0.43 & 0.99 & SRP uptake in the Western Interior Seaway \\
\hline BPF12 & 0.38 & 0.86 & SRP release in the surface water of the Western Interior Seaway \\
\hline BPF13 & 0.06 & 0.13 & SRP release in the shallow bottom water of the Western Interior Seaway \\
\hline BPF14 & 0.0005 & 0.001 & Organic P burial in the Western Interior Seaway \\
\hline BPF15 & 0.99 & 0.71 & SRP uptake in the northern coast \\
\hline BPF16 & 0.86 & 0.62 & SRP release in the surface water of the northern coast \\
\hline BPF17 & 0.13 & 0.09 & SRP release in the shallow bottom water of the northern coast \\
\hline BPF18 & 0.001 & 0.001 & Organic $\mathrm{P}$ burial in the northern coast \\
\hline BPF19 & 1.59 & 1.98 & SRP uptake in the southern coast \\
\hline BPF20 & 1.38 & 1.72 & SRP release in the surface water of the southern coast \\
\hline BPF21 & 0.20 & 0.26 & SRP release in the shallow bottom water of the southern coast \\
\hline BPF22 & 0.001 & 0.002 & Organic $\mathrm{P}$ burial in the southern coast \\
\hline BPF23 & 0.04 & 0.06 & SRP uptake in the north-eastern coast \\
\hline BPF24 & 0.03 & 0.05 & SRP release in the surface water of the north-eastern coast \\
\hline BPF25 & 0.005 & 0.007 & SRP release in the shallow bottom water of the north-eastern coast \\
\hline BPF26 & 0.00005 & 0.00007 & Organic $\mathrm{P}$ burial in the north-eastern coast \\
\hline BPF27 & 0.23 & 0.21 & SRP uptake in the Tethys gateway \\
\hline BPF28 & 0.2 & 0.18 & SRP release in the surface water of the Tethys gateway \\
\hline BPF29 & 0.03 & 0.03 & SRP release in the shallow bottom water of the Tethys gateway \\
\hline BPF30 & 0.0003 & 0.0003 & Organic $\mathrm{P}$ burial in the Tethys gateway \\
\hline BPF31 & 0.2 & 0.19 & Organic $\mathrm{P}$ export to the intermediate water in the central open ocean \\
\hline BPF32 & 0.04 & 0.04 & Organic $\mathrm{P}$ export to the bottom water in the central open ocean \\
\hline BPF33 & 0.27 & 0.22 & Organic $\mathrm{P}$ export to the intermediate water in the southern open ocean \\
\hline BPF34 & 0.06 & 0.05 & Organic P export to the bottom water in the southern open ocean \\
\hline PBF35 & 0.06 & 0.13 & Organic P export to the shallow bottom water in the Western Interior Seaway \\
\hline BPF36 & 0.13 & 0.09 & Organic $\mathrm{P}$ export to the shallow bottom water in the northern coast \\
\hline BPF37 & 0.21 & 0.26 & Organic $\mathrm{P}$ export to the shallow bottom water in the southern coast \\
\hline BPF38 & 0.005 & 0.008 & Organic $\mathrm{P}$ export to the shallow bottom water in the north-eastern coast \\
\hline BPF39 & 0.03 & 0.03 & Organic $\mathrm{P}$ export to the shallow bottom water in the Tethys gateway \\
\hline FePB1 & 0.00014 & 0.00016 & Inorganic Fe-P burial in the central open ocean \\
\hline CaPB1 & 0.00029 & 0.00029 & Inorganic $\mathrm{Ca}-\mathrm{P}$ burial in the central open ocean \\
\hline
\end{tabular}


continuation

\begin{tabular}{llll}
\hline Name & $\begin{array}{l}\text { P flux } \\
\text { pre-OAE2 }\end{array}$ & OAE2 & $\begin{array}{l}\text { Description } \\
\text { units in Tmol P y-1 }\end{array}$ \\
\hline FePB2 & 0.00016 & 0.0002 & Inorganic Fe-P burial in the southern open ocean \\
CaPB2 & 0.00037 & 0.00033 & Inorganic Ca-P burial in the southern open ocean \\
FePB3 & 0.00043 & 0.00045 & Inorganic Fe-P burial in the Western Interior Seaway \\
CaPB3 & 0.0009 & 0.0022 & Inorganic Ca-P burial in the Western Interior Seaway \\
FePB4 & 0.0009 & 0.001 & Inorganic Fe-P burial in the northern coast \\
CaPB4 & 0.0019 & 0.0018 & Inorganic Ca-P burial in the northern coast \\
FePB5 & 0.0004 & 0.0004 & Inorganic Fe-P burial in the southern coast \\
CaPB5 & 0.0017 & 0.0017 & Inorganic Ca-P burial in the southern coast \\
FePB6 & 0.00005 & 0.00005 & Inorganic Fe-P burial in the north-eastern coast \\
CaPB6 & 0.0001 & 0.00016 & Inorganic Ca-P burial in the north-eastern coast \\
FePB7 & 0.0002 & 0.0003 & Inorganic Fe-P burial in the Tethys gateway \\
CaPB7 & 0.0005 & 0.0005 & Inorganic Ca-P burial in the Tethys gateway \\
\hline
\end{tabular}


Table S5: Oxygen cycle: Reservoir sizes and fluxes for pre-OAE2 and OAE2 conditions as implemented in the multi-box model.

\begin{tabular}{|c|c|c|c|}
\hline Name & $\begin{array}{l}\mathrm{O}_{2} \text { reservoir } \\
\text { pre-OAE2 }\end{array}$ & & $\begin{array}{l}\text { Description } \\
\text { units Tmol } \mathrm{O}_{2}\end{array}$ \\
\hline OX1i & 987.95 & 1323.70 & Dissolved $\mathrm{O}_{2}$ in the intermediate water of the central open ocean \\
\hline OX1b & 5777.83 & 6991.77 & Dissolved $\mathrm{O}_{2}$ in the bottom water of the central open ocean \\
\hline OX2i & 54.28 & 130.72 & Dissolved $\mathrm{O}_{2}$ in the intermediate water of the southern open ocean \\
\hline $\mathrm{OX} 2 \mathrm{~b}$ & 900.53 & 1175.8 & Dissolved $\mathrm{O}_{2}$ in the bottom water of the southern open ocean \\
\hline OX3b & 17.77 & 51.87 & Dissolved $\mathrm{O}_{2}$ in the shallow bottom water of the Western Interior Seaway \\
\hline $\mathrm{OX} 4 \mathrm{~b}$ & 39.6 & 64.38 & Dissolved $\mathrm{O}_{2}$ in the shallow bottom water of the northern coast \\
\hline OX5b & 10.11 & 14.64 & Dissolved $\mathrm{O}_{2}$ in the shallow bottom water of the southern coast \\
\hline OX6b & 20.18 & 30.8 & Dissolved $\mathrm{O}_{2}$ in the shallow bottom water of the north-eastern coast \\
\hline OX7b & 12.78 & 19.65 & Dissolved $\mathrm{O}_{2}$ in the shallow bottom water of the Tethys gateway \\
\hline Name & $\begin{array}{l}\mathrm{O}_{2} \text { flux } \\
\text { pre-OAE2 }\end{array}$ & OAE2 & $\begin{array}{l}\text { Description } \\
\text { units in Tmol } \mathrm{O}_{2} \mathrm{y}-1\end{array}$ \\
\hline & & & Fluxes coupled to the water cycle \\
\hline OF3 & 33.44 & 71.82 & Intermediate $\left[\mathrm{O}_{2}\right]$ of the central open ocean times $\mathrm{F} 3$ \\
\hline OF6 & 90.76 & 145.14 & Bottom $\left[\mathrm{O}_{2}\right]$ of the Pacific Ocean times F6 \\
\hline OF10 & 3.9 & 31.9 & Shallow bottom $\left[\mathrm{O}_{2}\right]$ of the Tethys times F10 \\
\hline OF16 & 66.51 & 107.51 & Intermediate $\left[\mathrm{O}_{2}\right]$ of the central open ocean times F16 \\
\hline OF17 & 10.46 & 37.11 & Bottom $\left[\mathrm{O}_{2}\right]$ of the central open ocean times F17 \\
\hline OF20 & 37.4 & 43.86 & Intermediate $\left[\mathrm{O}_{2}\right]$ of the central open ocean times F20 \\
\hline OF21 & 20.67 & 60.59 & Bottom $\left[\mathrm{O}_{2}\right]$ of the northern coast times $\mathrm{F} 21$ \\
\hline OF22 & 2.2 & 13.67 & Intermediate $\left[\mathrm{O}_{2}\right]$ of the central open ocean times F22 \\
\hline OF23 & 0.45 & 40.95 & Intermediate $\left[\mathrm{O}_{2}\right]$ of the central open ocean times $\mathrm{F} 23$ \\
\hline OF24 & 4.37 & 2.73 & Bottom $\left[\mathrm{O}_{2}\right]$ of the southern coast times F24 \\
\hline OF25 & 0.58 & 31.84 & Bottom $\left[\mathrm{O}_{2}\right]$ of the central open ocean times $\mathrm{F} 25$ \\
\hline OF26 & 10.78 & 11.04 & Surface $\left[\mathrm{O}_{2}\right]$ of the Tethys gateway times F26 (downwelling) \\
\hline OF27 & 9.36 & 16.95 & Bottom $\left[\mathrm{O}_{2}\right]$ of the Tethys gateway times F27 (upwelling) \\
\hline OF28 & 4.62 & 8.07 & Surface $\left[\mathrm{O}_{2}\right]$ of the southern coast times F28 (downwelling) \\
\hline OF29 & 4.1 & 5.75 & Bottom $\left[\mathrm{O}_{2}\right]$ of the southern coast times F29 (upwelling) \\
\hline OF31 & 32.87 & 38.18 & Surface $\left[\mathrm{O}_{2}\right]$ of the Western Interior Seaway times F31 (downwelling) \\
\hline OF32 & 27.77 & 31.13 & Bottom $\left[\mathrm{O}_{2}\right]$ of the Western Interior Seaway times F32 (upwelling) \\
\hline OF33 & 33.97 & 24.17 & Surface $\left[\mathrm{O}_{2}\right]$ of the northern coast times $\mathrm{F} 33$ (downwelling) \\
\hline OF34 & 30.22 & 20.32 & Bottom $\left[\mathrm{O}_{2}\right]$ of the northern coast times $\mathrm{F} 34$ (upwelling) \\
\hline OF35 & 7.22 & 20.8 & Surface $\left[\mathrm{O}_{2}\right]$ of the north-eastern coast times $\mathrm{F} 35$ (downwelling) \\
\hline OF36 & 2.12 & 6.23 & Bottom $\left[\mathrm{O}_{2}\right]$ of the north-eastern coat times F36 (upwelling) \\
\hline OF37 & 30.27 & 90.81 & Intermediate $\left[\mathrm{O}_{2}\right]$ of the central open ocean times F37 \\
\hline OF38 & 100.43 & 180.96 & Bottom $\left[\mathrm{O}_{2}\right]$ of the central open ocean times F38 \\
\hline OF43 & 1.82 & 22.78 & Bottom $\left[\mathrm{O}_{2}\right]$ of the Tethys gateway times $\mathrm{F} 43$ \\
\hline OF44 & 7.26 & 8.53 & $\begin{array}{l}\text { Bottom }\left[\mathrm{O}_{2}\right] \text { of the north-eastern coast times F44 in pre-OAE2 } \\
\text { Bottom }\left[\mathrm{O}_{2}\right] \text { of the Tethys gateway times F44 in OAE2 }\end{array}$ \\
\hline OF45 & 0.66 & 35.73 & $\begin{array}{l}\text { Bottom }\left[\mathrm{O}_{2}\right] \text { of the northern coast times } \mathrm{F} 45 \text { in pre-OAE2 } \\
\text { Bottom }\left[\mathrm{O}_{2}\right] \text { of the north-eastern coast times } \mathrm{F} 45 \text { in OAE2 }\end{array}$ \\
\hline OF46 & 34.92 & 33.47 & Bottom $\left[\mathrm{O}_{2}\right]$ of the Western Interior Seaway times F46 \\
\hline OF49 & 30.14 & 9.94 & Intermediate $\left[\mathrm{O}_{2}\right]$ of the central open ocean times F49 \\
\hline OF50 & 35.84 & 52.13 & Intermediate $\left[\mathrm{O}_{2}\right]$ of the central open ocean times F50 \\
\hline
\end{tabular}


continuation

\begin{tabular}{|c|c|c|c|}
\hline Name & $\begin{array}{l}\mathrm{O}_{2} \text { flux } \\
\text { pre-OAE2 }\end{array}$ & OAE2 & $\begin{array}{l}\text { Description } \\
\text { units in Tmol } \mathrm{O}_{2} \mathrm{y}-1\end{array}$ \\
\hline OF51 & 13.91 & 31.22 & Intermediate $\left[\mathrm{O}_{2}\right]$ of the southern open ocean times F51 \\
\hline OF52 & 72.71 & 96.31 & Bottom $\left[\mathrm{O}_{2}\right]$ of the central open ocean times F52 \\
\hline OF53 & 58.76 & 78.86 & Bottom $\left[\mathrm{O}_{2}\right]$ of the southern open ocean times F53 \\
\hline OF55 & 0.72 & 0.94 & Surface $\left[\mathrm{O}_{2}\right]$ of the southern open ocean times F55 (downwelling) \\
\hline OF56 & 3.94 & 9.5 & Intermediate $\left[\mathrm{O}_{2}\right]$ of the southern open ocean times F56 (upwelling) \\
\hline OF57 & 0.41 & 0.99 & Intermediate $\left[\mathrm{O}_{2}\right]$ of the southern open ocean times F57 \\
\hline OF58 & 6.5 & 9.5 & Bottom $\left[\mathrm{O}_{2}\right]$ of the southern open ocean times F58 \\
\hline OF59 & 0.45 & 2.23 & $\begin{array}{l}\text { Bottom }\left[\mathrm{O}_{2}\right] \text { of the southern coast times } \mathrm{F} 59 \text { in pre-OAE2 } \\
\text { Bottom }\left[\mathrm{O}_{2}\right] \text { of the southern open ocean times F59 in OAE2 } \\
\text { Fluxes coupled to the } \mathbf{C} \text { and } \mathbf{P} \text { cycles }\end{array}$ \\
\hline BOF3 & 21.32 & 20.02 & $\mathrm{O}_{2}$ consumption in the intermediate water of the central open ocean \\
\hline BOF4 & 6.07 & 5.7 & $\mathrm{O}_{2}$ consumption in the bottom water of the central open ocean \\
\hline BOF8 & 29.16 & 23.55 & $\mathrm{O}_{2}$ consumption in the intermediate water of the southern open ocean \\
\hline BOF9 & 8.3 & 6.71 & $\mathrm{O}_{2}$ consumption in the bottom water of the southern open ocean \\
\hline BOF13 & 7.58 & 17.43 & $\mathrm{O}_{2}$ consumption in the shallow bottom water in the Western Interior Seaway \\
\hline BOF17 & 17.33 & 12.46 & $\mathrm{O}_{2}$ consumption in the shallow bottom water in the northern coast \\
\hline BOF21 & 27.67 & 34.54 & $\mathrm{O}_{2}$ consumption in the shallow bottom water in the southern coast \\
\hline BOF25 & 0.71 & 1.02 & $\mathrm{O}_{2}$ consumption in the shallow bottom water in the north-eastern coast \\
\hline BOF29 & 3.98 & 3.68 & $\mathrm{O}_{2}$ consumption in the shallow bottom water in the Tethys gateway \\
\hline
\end{tabular}


Table S6: Linear equations as implemented in the model for fluxes in oxic conditions. The $k_{*}$ is a rate constant $\left(\mathrm{y}^{-1}\right) . S R P$ is the reservoir of soluble reactive $\mathrm{P}, P O C$ and $P O P$ are the reservoirs for particulate organic $\mathrm{C}$ and $\mathrm{P}$, respectively. ${ }_{s}$ : surface water; $i$ : intermediate water; ${ }_{b}$ : bottom water.

\begin{tabular}{|c|c|}
\hline Flux & Linear equations \\
\hline C cycle & $\left(\mathbf{T m o l ~ C \mathbf { y } ^ { - 1 }}\right)$ \\
\hline Primary productivity in surface ocean & $P P=k_{P P} \cdot S R P_{s} \cdot 106^{[1]}$ \\
\hline Inorganic $\mathrm{C}$ release in surface ocean & $C R E L_{s}=k_{C R E L_{s}} \cdot P O C_{s}{ }^{[1]}$ \\
\hline Inorganic $\mathrm{C}$ release in intermediate open ocean & $C R E L_{i}=k_{C R E L_{i}} \cdot P O C_{i}{ }^{[1]}$ \\
\hline Inorganic $\mathrm{C}$ release in shallow/deep bottom ocean & $C R E L_{b}=k_{C R E L_{b}} \cdot P O C_{b}{ }^{[1]}$ \\
\hline POC Export in surface to intermediate/shallow bottom ocean & $C E X P_{s}=P O P E X P_{s} * 106^{[1]}$ \\
\hline POC Export in intermediate to deep bottom open ocean & $C E X P_{i}=P O P E X P_{i} * 106^{[1]}$ \\
\hline POC burial in coastal ocean & $C B U R=k_{C B U R} \cdot C E X P_{S}{ }^{[1]}$ \\
\hline POC burial in open ocean & $C B U R=k_{C B U R} \cdot\left(C E X P_{s}+C E X P_{i}\right)^{[2]}$ \\
\hline P cycle & $\left(\mathbf{T m o l} \mathbf{P} \mathbf{y}^{-1}\right)$ \\
\hline SRP uptake in surface ocean & $S R P U=P P / 106^{[1]}$ \\
\hline SRP release in surface ocean & $P R E L_{s}=C R E L_{s} / 106^{[1]}$ \\
\hline SRP release in intermediate open ocean & $P R E L_{i}=C R E L_{i} / 106^{[1]}$ \\
\hline SRP release in shallow/deep bottom ocean & $P R E L_{b}=k_{P R E L_{b}} \cdot P O P_{b}{ }^{[1]}$ \\
\hline POP Export from surface to intermediate/shallow bottom & $P O P E X P_{s}=k_{P O P E X P_{s}} * P O P_{s}[1]$ \\
\hline POP Export from intermediate to deep bottom ocean & $P O P E X P_{i}=k_{P O P E X P_{i}} * P_{O P}[1]$ \\
\hline POP burial in coastal ocean & $P O P B U R=C B U R / 200[3]$ \\
\hline POP burial in open ocean & $P O P B U R=C B U R / 106^{[1]}$ \\
\hline Ca-P burial in shallow/deep bottom ocean & $C a P B U R=k_{C a P B U R} \cdot P R E L_{b}{ }^{[1]}$ \\
\hline Fe-P burial in shallow/deep bottom ocean & $F e P B U R=F e P B U R_{\text {oxic }} \cdot \frac{\left[\mathrm{O}_{2}\right]}{\left[\mathrm{O}_{2}\right]_{\text {crit }}}[1]$ \\
\hline $\mathbf{O}_{2}$ cycle & $\left(\mathbf{T m o l ~} \mathbf{O}_{2} \mathbf{y}^{-1}\right)$ \\
\hline $\mathrm{O}_{2}$ consumption in intermediate open ocean & $O C O N_{i}=C R E L_{i} \cdot 138 / 106^{[1]}$ \\
\hline $\mathrm{O}_{2}$ consumption in shallow/deep bottom ocean & $O C O N_{b}=C R E L_{b} \cdot 138 / 106^{[1]}$ \\
\hline
\end{tabular}

[1]Slomp and Van Cappellen, 2007, [2] This study, [3]Van Cappellen and Ingall, 1994

\section{References}

Arthur, M. A. and Dean, W. A. Pratt, L. M.: Geochemical and climatic effects of increased marine organic carbon burial at the Cenomanian-Turonian boundary, Nature, 335, 714-717, doi:10.1038/335714a0, 1988.

Austin, J. A., Schlager, W., Palmer, A. A., and et al.: Site 632 A/B, in Proceedings and initial reports (Part A) of the Ocean Drilling Program, Leg 101, College Station, Texas A\&M University, p. 569, doi: 10.2973/odp.proc.ir.101.111, 1986.

Barker, C. E., Pawlewicz, M., and Cobabe, E. A.: Deposition of sedimentary organic matter in black shale facies indicated by the geochemistry and petrography of high-resolution samples, Blake Nose, western North Atlantic, Geological Society, London, Special Publications, 183, 49-72, doi:10.1144/GSL.SP.2001.183.01.03, 2001.

Bowman, A. R. and Bralower, T. J.: Paleoceanographic significance of high-resolution carbon isotope records across the Cenomanian-Turonian boundary in the Western Interior and New Jersey coastal plain, USA, Marine Geology, 217, 305-321, 2005.

Herbin, J. P., Montadert, L., Miiller, C., Gomez, R., Thurow, J., and Wiedmann, J.: Organic-rich sedimentation at 
the Cenomanian-Turonian boundary in oceanic and coastal basins in the North Atlantic and Tethys, Geological Society Special Publication, 21, 389-422, 1986.

Hetzel, A., Böttcher, M. E., Wortmann, U. G., and Brumsack, H.-J.: Paleo-redox conditions during OAE 2 reflected in Demerara Rise sediment geochemistry (ODP Leg 207), Palaeogeography Palaeoclimatology Palaeoecology, 273, 302-328, 2009.

Hetzel, A., März, C., Vogt, C., and Brumsack, H.-J.: Geochemical environment of Cenomanian-Turonian black shale deposition at Wunstorf (northern Germany), Cretaceous Research, 32, 480-494, 2011.

Kolonic, S., Wagner, T., Forster, A., Sinninghe Damsté, J. S., Walsworth-Bell, B., Erba, E., Turgeon, S., Brumsack, H.-J., Hassane Chellai, E., Tsikos, H., Kuhnt, W., and Kuypers, M. M. M.: Black shale deposition on the northwest African Shelf during the Cenomanian-Turonian oceanic anoxic event: Climate coupling and global organic carbon burial, Paleoceanography, 20, 95-128, doi:10.1029/2003PA000950, 2005.

Kraal, P., Slomp, C. P., Forster, A., and Kuypers, M. M. M.: Phosphorus cycling from the margin to abyssal depths in the proto-Atlantic during oceanic anoxic event 2, Palaeogeography Palaeoclimatology Palaeoecology, 295, 42-54, 2010 b.

Kuhnt, W. and Wiedmann, J.: Cenomanian-Turonian source rocks: paleobiogeographic and paleoenvironmental aspects, In: Huc, A. Y. (Ed.) : Paleogeography, Paleoclimate and Source Rocks. AAPG studies in Geology, 40, 213-231, 1995.

Kuhnt, W., Herbin, J. P., Thurow, J. W., and Wiedmann, J.: Distribution of Cenomanian-Turonian organic facies in the western Mediterranean and along the Adjacent Atlantic Margin, AAPG Studies in Geology, 30, 133160, 1990.

Kuypers, M. M. M., Pancost, R. D., Nijenhuis, I. A., and Sinninghe Damsté, J. S.: Enhanced productivity led to increased organic carbon burial in the euxinic North Atlantic basin during the late Cenomanian oceanic anoxic event, Paleoceanography, 17, 1-13, 2002.

Kuypers, M. M. M., Lourens, L. J., Rijpstra, W. I. C., Pancost, R. D., Nijenhuis, I. A., and Sinninghe Damsté, J. S.: Orbital forcing of organic carbon burial in the proto-North Atlantic during oceanic anoxic event 2, Earth and Planetary Science Letters, 228, 465-482, 2004.

Lancelot, Y., Winterer, E. L., and et al.: Init. Rep. Deep Sea Drilling Project 50: Washington (U.S. Govt. Printing Office), 1980.

Meyers, S., Sageman, B., and Hinnov, L.: Integrated quantitative stratigraphy of the Cenomanian-Turonian Bridge Creek Limestone Member using evolutive harmonic analysis and stratigraphic modeling, Journal of Sedimentary Research, 71, 627-643, 2001.

Mort, H. P., Adatte, T., Föllmi, K. B., Keller, G., Steinmann, P., Matera, V., Berner, Z., and Stüben, D.: Phosphorus and the roles of productivity and nutrient recycling during oceanic anoxic event 2, Geology, 35, 483-486, 2007.

Mort, H. P., Adatte, T., Keller, G., Bartels, D., Föllmi, K. B., Steinmann, P., Berner, Z., and Chellai, E. H.: Organic carbon deposition and phosphorus accumulation during Oceanic Anoxic Event 2 in Tarfaya, Morocco, Cretaceous Research, 29, 1008-1023, 2008.

Nederbragt, A. J., Thurow, J., Vonhof, H., and Brumsack, H.-J.: Modelling oceanic carbon and phosphorus fluxes: implications for the cause of the late Cenomanian Oceanic Anoxic Event (OAE2), Journal of the Geological Society of London, 161, 721-728, doi:10.1144/0016-764903-075, 2004.

Norris, R. D., Kroon, D., and Klaus, A.: CretaceousPaleogene climatic evolution of the western North Atlantic: results from ODP Leg 171B, Blake Nose, In Kroon, D., Norris, R. D., and Klaus, A. (Eds.), Proc. ODP, Sci. Results, 171B: College Station, TX (Ocean Drilling Program), 161, 1-10, doi:10.2973/odp.proc.sr.171b.101, 2001.

Owens, J. D., Lyons, T. W., Li, X., Macleod, K. G., Gordon, G., Kuypers, M. M. M., Anbar, A., Kuhnt, W., and Severmann, S.: Iron isotope and trace metal records of iron cycling in the proto-North Atlantic during the Cenomanian-Turonian oceanic anoxic event (OAE-2), Palaeogeography, 27, 1-13, doi: 10.1029/2012PA002328, 2012. 
Pancost, R. D., Crawford, N., Magness, S., Turner, A., Jenkyns, H. C., and Maxwell, J. R.: Further evidence for the development of photic-zone euxinic conditions during Mesozoic oceanic anoxic events, Journal of the Geological Society of London, 161, 353-364, doi:10.1144/0016764903-059, 2004.

Rodríguez-Tovar, F. J., Uchman, A., Payros, A., Orue-Etxebarria, X., Apellaniz, E., and Molina, E.: Sealevel dynamics and palaeoecological factors affecting trace fossil distribution in Eocene turbiditic deposits (Gorrondatxe section, N Spain), Palaeogeography Palaeoclimatology Palaeoecology, 285, 50-65, doi: 10.1016/j.palaeo.2009.10.022, 2010.

Sinninghe Damsté, J. S. and Köster, J.: A euxinic southern North Atlantic Ocean during the CenomanianTuronian oceanic anoxic event, Earth and Planetary Science Letters, 158, 165-173, doi:10.5194/cp-3-6472007, 1998.

Sinninghe Damsté, J. S., van Bentum, E. C., Reichart, G.-J., Pross, P., and Schouten, S.: A CO 2 decrease-driven cooling and increased latitudinal temperature gradient during the mid-Cretaceous Oceanic Anoxic Event 2, Earth and Planetary Science Letters, 293, 97-103, doi:10.1016/j.epsl.2010.02.027, 2010.

Slomp, C. P. and Van Cappellen, P.: The global marine phosphorus cycle: sensitivity to oceanic circulation, Biogeosciences, 4, 155-171, 2007.

Snow, L. J., Duncan, R. A., and Bralower, T. J.: Trace element abundances in the Rock Canyon anticline, Pueblo, Colorado, marine sedimentary section and their relationship to Caribbean plateau construction and oxygen anoxic event 2, Paleoceanography, 20, doi:10.1029/2004PA001093, 2005.

Sugarman, P. J., Miller, K. G., Olsson, R. K., Browning, J. V., Wright, J. D., de Romero, L. M., White, T. S., Muller, F. L., and Uptegrove, J.: The Cenomanian-Turonian carbon burial event, Bass River, NJ, USA: Geochemical, paleoecological, and sea-level changes, Journal of Foraminiferal Research, 29, 438-452, 1999.

Thurow, J. W., Moullade, M., Brumsack, H.-J., Masure, E., Taugourdou, J., and Dunham, K.: The CenomanianTuronian Boundary Event (CTBE) at Leg 103/Hole 641A, Proceedings of the Ocean Drilling Program Scientific Results, 103, 587-634, 1988.

Topper, R. P. M., Trabucho Alexandre, J., Tuenter, E., and Meijer, P. Th.: A regional ocean circulation model for the mid-Cretaceous North Atlantic Basin: implications for black shale formation, Climate of the past, 7 , 277-297, 2011.

Urquhart, E., Gardin, S., Leckie, R. M., Wood, S. A., Pross, J., Georgescu, M. D., Ladner, B., and Takata, H.: A Paleontological Synthesis of ODP Leg 210, Newfoundland Basin, In Tucholke, B.E and Sibuet, J. C and and Klaus, A. (Eds.), Proc. ODP, Sci. Results, 210: College Station, TX (Ocean Drilling Program), pp. 1-53, 2007.

van Bentum, E. C., Hetzel, A., Brumsack, H.-J., Forster, A., Reichart, G.-J., and Sinninghe Damsté, J. S.: Reconstruction of water column anoxia in the equatorial Atlantic during the Cenomanian-Turonian oceanic anoxic event using biomarker and trace metal proxies, Palaeogeography Palaeoclimatology Palaeoecology, 280, 489-498, 2009.

van Bentum, E. C., Reichart, G.-J., and Sinninghe-Damsté, J. S.: Organic matter provenance, palaeoproductivity and bottom water anoxia during the Cenomanian/Turonian oceanic anoxic event in the Newfoundland Basin (northern proto North Atlantic Ocean), Organic Geochemistry, 50, 11-18, 2012.

Van Cappellen, P. and Ingall, E. D.: Benthic phosphorus regeneration, net primary production, and ocean anoxia: A model of the coupled marine biogeochemical cycles of carbon and phosphorus, Paleoceanography, 9, 677692, 1994.

Voigt, S.: Cenomanian-Turonian composite $\delta^{13} \mathrm{C}$ curve for Western and Central Europe: the role of organic and inorganic carbon fluxes, Palaeogeography Palaeoclimatology Palaeoecology, 160, 91-104, 2000. 